\title{
The quality of water in dental offices from the public healthcare system of a Brazilian town: a study of the microbial, physical and chemical parameters
}

\begin{abstract}
Water used on dental equipment can represent a source of infections It was assessed the quality of water in dental offices in 14 healthcare facilities of a Brazilian town. It was harvested samples to analysis in different locations: water reservoir, tap, dental unit water tank and three-way syringe. The samples were evaluated under methodologies for microbial (identification of total coliforms and thermotolerants coliforms; heterotrophic bacteria counting), chemical (free residual chlorine content) and physical (turbidity) analysis. None of the sample showed thermotolerants coliforms, however, total coliforms were identified in one tap and two tanks. Considering the percentage of healthcare facilities under study, the heterotrophic plate count indicated unaccepted values in the tap $(0.07 \%)$, dental unit tank $(100 \%)$ and three-way syringe $(92 \%)$, disclosing a significant statistical difference $(\mathrm{p}<0,001-\mathrm{F}-\mathrm{Test}$ - ANOVA Bonferroni comparisons). The percentages of chlorine on the samples were adequate in only $15 \%$ of tanks of the dental units. The turbidity presented inadequate standards in 1 tap and in 1 tank from three different facilities. It was observed that none of the healthcare facilities presented water to be considered adequate, according to the standard of the Ministry of Health, a worrying fact that may bring consequences to the health of the population.
\end{abstract}

Keywords: water storage, dental offices quality of water
Volume 9 Issue 5 - 2018

\author{
Marcela Côrte Real Fernandes,' Paula \\ Baptistella Lima,' Maria Torres Calazans,'2 \\ Fábio Barbosa de Souza' \\ 'Departament of Prosthetics and Orofacial Surgery, Federal \\ University of Pernambuco, Brazil \\ ${ }^{2}$ Department of Antibiotic, Biological Science Centre, Federal \\ University of Pernambuco, Brazil
}

\begin{abstract}
Correspondence: Fábio Barbosa de Souza, Federal University of Pernambuco, Department of Prosthetics and Orofacial Surgery,Av. Prof. Moraes Rego s/n, Cidade Universitária, Recife-PE, CEP/POSTCODE: 50670-90I,Tel +558121268830; +558199748237, Fax +558I21268344,

Email fabiobdsowza@gmail.com
\end{abstract}

Received: September 18, 2018| Published: October 12, 2018

\section{Introduction}

Water represents a fundamental resource to the survival of the human race, reflecting decisively over health of the populations. Besides the nutritional aspects, it has a crucial role regarding personal hygiene and its use for the Public Health Service. More than its beneficial characteristics, it can become an ideal natural substratum to the growth and dissemination of microorganisms, becoming a villain on the emergences of diseases and epidemic outbreaks. In this regard, water must attend minimum standards of quality to human consumption, which, Brazil has been taken under regards in Ordinance $n^{\circ} 2.914$ by Ministry of Health. ${ }^{1}$

In dental offices, hand-pieces the dental unit waterlines are always in contact with water, creating an environmental susceptible to the growth of microorganisms. ${ }^{2}$ During the clinical conducts - prophylaxes, restoration treatments, endodontic treatments, periodontal treatments, among others - water being used may be ingested by the user throughout the public healthcare service, as it can also meet solutions of continuity on the mucosa and/or teeth, accessing directly to connective tissue under the possibility of absorbance and reach of circulatory system. Hence, the quality of water used in dental offices must have severe control standards, in which, according to the American Dental Association - ADA, it must not be more than 200 colony-forming units (CFU) per $\mathrm{ml}$ of its composition. ${ }^{3}$

According to Souza-Gugelmin et al. ${ }^{4}$ crossed infections may occur in dental offices regarding its water that are stored in the dental unit tank and after is transferred to the equipment and touching the oral cavity of the patients. This conclusion was obtained after a performance of a study that had its intentions demonstrate the occurrence of contamination on the waterlines of the dental equipment in dental offices in Ribeirao Preto, a city southeast Brazil. Water samples were collected from tanks, three-way syringe and high-speed turbine in fifteen work units. From total analysed, thirteen tanks were contaminated. The samples from the three-way syringe and turbine showed an increase of the contamination regarding the corresponding tank.

In addition, the ambulatories environment regarding dental treatment executions, by itself, is the local where occurs a potential chain of crossed infections, through the equipment and dental staff contamination. An example is the fact that a great number of microorganisms in the oral cavity are being vacuumed and disposed into the dental unit waterlines, where they can be colonised by bacteria, fungus and protozoa. ${ }^{5}$ Those systems originate from a favourable environment to the biofilm growth on the internal surfaces of the waterlines and, in consequence, they can propitiate an infection.

The contamination of water of the dental units were the object of research of Chibebe, Ueno and Pallos, ${ }^{6}$ which analysed microbiologically forty samples of water and its possible correlation with the tank type, supply and its cleaning. The results show that 29 offices were with contaminated water. The influence of the type of tank contrasted significately on the degree of contamination of the water, once the tank "pet" type presented a lower level of contamination, therefore not having a great difference to the type of supply and cleaning. It was concluded that $72.5 \%$ of the dental offices contained contaminated water according to the recommendation of ADA, offices from the public health system the local presenting the highest levels of contamination. 
Therefore, directing the focus to the analysis of water on the healthcare services associated to the Public Health System demonstrates being fundamental. Under this approach, the town of Cabo de Santo Agostinho, located northeast Brazil, has been gaining ground as a health service provider of the State of Pernambuco. Specially due to its significant addition on its population density, in virtue of the Suape Industrial Complex. More than 79 corporations are installed or under implementation on the Industrial Complex, representing a 1.7billion dollar on investments. In consequence, along the growth of population at this location, there is an increase of public health service demand, including the dental treatments.

Coming to a conclusion, thus, in which the contamination of water used in the facilities of public health service is a reality, bringing consequences to the individual and the population. However, researches conducted to the control of the water for the dental procedures are very scarce. When it occurs, neither was presented an epidemiological representativeness nor was taken into account doubtable or surpassed methods. Even so, establishing a diagnosis of the actual status of water in the public oral healthcare network became fundamental to the planning and execution of the measures regarding the control of the quality of water in public dental offices. It was assessed the microbial, chemical and physical quality of the water in dental offices of the public health system in the town of Cabo de Santo Agostinho.

\section{Materials and methods}

All healthcare facilities of the public healthcare facilities of the town with public dental offices $(n=14)$ were analysed, in which were supplied with certified water from the public supply network. The quality of water was assessed according the methodologies to microbial analysis (total and thermotolerants coliforms; heterotrophic bacteria), chemical (free residual chlorine content) and physical (turbidity). These analyses were taken at the Vigiágua Laboratory of the Environmental Monitoring of the Town of Cabo de Santo Agostinho and in the Department of Antibiotic of the Biological Sciences Centre of the Federal University of Pernambuco (UFPE). Independent of the methodology chosen, the activities were executed in two phases: field (in situ) and in laboratory (ex situ).

\section{Field study (in situ)}

In each health facility, five samples of water were harvested to analysis in distinctive locations. First location was always the cistern of water coming from the supply network; second harvesting was done in the internal supply of the facility, preferable on a tap inside the dental offices and the third location was the water stored inside the tanks of the dental unit. The samples obtained from these three locations were analysed in the Vigiágua Laboratory, where were submitted to methodological procedures for total and thermotolerants coliforms; turbidity and residual chlorine levels. The fourth location of harvesting was also done at the tank of the dental unit, and the fifth were samples obtained from the three-way syringe of the dental unit. The last two were designed to the heterotrophic plate count, done on the dependencies of the Antibiotic Department of the UFPE.

Prior to the water harvesting, sanitation was taken done to the harvesting points (tap, tanks and three-way syringe) using alcohol $70 \%$. Following, either the tap or the three-way syringe were action in order to let the water flow for one minute, minimum. This practice allowed the discarding of the residual content of the pipes and plumbing, as the harvesting of possible debris. For this phase, the operator was equipped with personal protective equipment (PPE) necessary in order to avoid any contamination (lab coat, gloves, mask, bouffant and safety goggles). The samples were harvested directly into a sterilised plastic container (Thio-Bag), specific to this practice, with $100 \mathrm{ml}$ capacity for liquids. Each sample had its data put into a harvesting worksheet, later identified, packed coolers and sent to respective analysis laboratory.

\section{Laboratory work (ex situ)}

Before the arrival of the samples, the benches of the inoculation room in the laboratory were disinfected with alcohol a $70 \%$. During all procedure, the operator used the proper PPE, that comprehends lab coat, gloves, mask, safety goggles and bouffant. All parameters, physic-chemical and biological were analysed according to the present Ordinance 2.914/11 that establishes the quality standard of the water destined to human consumption.

\section{Total and thermotolerants coliforms (escherichia coli)}

To the bacterial analysis, which the coliforms are designed to, chromogenic substrate, were used. The inoculation was done directly at the sample container (ThioBag) through the addition of an ampoule to the medium (Colilert $\AA$ ) enough to $100 \mathrm{ml}$ of water. After this phase, the sample was homogenised and stored in a bacteriological incubator for $24 \mathrm{hr}$ and $48 \mathrm{hr}$ at a temperature of $35^{\circ} \mathrm{C}$. This technique is based upon the offer of a medium as a specific subtract to the bacterial growth. The subtract, when associated with the enzymes produced by the bacteria, offers a colouring specific to the sample, allowing the it's reading. So, when the sample remains noncolour after the incubation, the result is negative for coliforms. When it is a yellow colouring, it will be positive for total coliforms. In case of confirmation for total coliforms and the sample display fluorescence under the ultraviolet light, the result is positive for total coliforms and also for thermotolerants simultaneously.

\section{Heterotrophic bacteria}

The heterotrophic bacteria analysis was performed through the determination of the amount of colonies in dishes (colonies developed in Petri dishes with glucose-nourished agar medium, aerobic incubated at $35^{\circ} \mathrm{C}$ up to 72 hours). In order to ensure the counting on the dishes, in addition to the inoculation of the original sample, ten-fold dilution were performed, varying from $1 / 10$ up to $1 / 100$ when needed. Those dilutions were performed in vessels or tubes with buffered water $\left(\mathrm{KH}_{2} \mathrm{PO}_{4}\right)$ or tap sterile distilled water. Each sample was thoroughly monitored before the beginning of the dilutions. Using tubes, the first dilution was done (1/10) using $1 \mathrm{ml}$ from the sample in $9 \mathrm{ml}$ of sterile buffered water. From then one, it was shaken vigorously and $1 \mathrm{ml}$ were transferred into another tube of $9 \mathrm{ml}$ of sterile buffered water $(1 / 100)$, practice done until the preferable dilutions were achieved.

For every dilution $1 \mathrm{ml}$ was transferred to each sterile Petri dish and added 10 to $15 \mathrm{ml}$ of glucose agar medium (GA) melted and cooled between 42 to $45^{\circ} \mathrm{C}$. After, the dishes were shaken with circle movements both ways and, at the to two perpendicular diameters, avoiding then the contamination of the cover. After solidification, each dish was incubated in an incubator at $35^{\circ} \mathrm{C}$ during 24 hours. After the incubation, a counting of the colonies with help of a colony counter Quebec type characterised for being a special device with magnifying glass. The final result came according the average of the number of colonies in the dishes $\mathrm{x}$ reciprocal of the dilution. Valid to the dishes chosen originated from any of the dilutions. 


\section{Residual free chlorine}

The evaluation of the level of residual free chlorine aimed to verify if the amount of this microbicide had a sufficient amount, taking into account what is recommended by the Ordinance 2.914/11. After the addition of an aliquot of the sample to the reagent to the chlorine test (DPD), the amount of this parameter was measured using a digital bench colorimeter.

\section{Turbidity}

The analysis of the turbidity indicated the quantity of particles suspended in the water measured by turbidity unit (FTU) It is very important due to the fact the particles suspended can either be a fixation subtract or source for the microorganisms. The turbidity was measured using a digital bench turbidity meter.

The data collected at each of the methodologies were submitted to statistical treatment to a level of significance of $\alpha=0,05(5 \%)$

\section{Results}

The microbial qualitative analysis of the water from dental offices of the healthcare facilities indicated an existence of total coliforms in some samples, as shown in Table 1. It wasn't identified the presence of thermotolerant coliforms at the samples analysed.

Table 2 displays the results from the heterotrophic plate count at all three locations under analysis and decimal logarithm of the number used to the statistic comparison test between the locations. The reason to the use of the logarithm was due to the large visibility of the scale with null values or mostly multiples of 10 . Using the method for multiple comparisons (among every couple of locations) did not prove a significant difference between the tap inside the office and each one of either harvesting location.

The percentages of chlorine at the samples were accordingly in $56 \%$ of the cisterns, $72 \%$ of the taps and $15 \%$ of the tanks. For turbidity, only 1 tap and in 1 tank from 2 different facilities were considered with inadequetaded standards.

Table 3 displays the findings from the analysis of the physical and chemical parameters of the water (chlorine and turbidity).

Table I Research evaluation of coliforms according to the harvesting location

\begin{tabular}{llllllll}
\hline \multirow{2}{*}{ Coliforms } & \multicolumn{2}{l}{ Place of harvesting } & & & & \\
& Water reservoir & \multicolumn{2}{l}{ Dental office tap } & \multicolumn{2}{c}{ Dental unit tank } & P value \\
& $\mathbf{n}$ & $\%$ & $\mathbf{n}$ & $\%$ & $\mathbf{n}$ & $\%$ & \\
\hline Absente & 5 & 100,0 & 13 & 92,9 & 12 & 85,7 & $\mathrm{P}(\mathrm{I})=1,000$ \\
Present (Type total) & - & - & 1 & 7,1 & 2 & 14,3 & \\
Total & 5 & 100,0 & 14 & 100,0 & 14 & 100,0 & \\
\hline
\end{tabular}

(I): Using the McNemmar method between the locations (dental office tap and dental unit tank)

Table 2 Average, standard deviation and median of the number and the decimal logarithm of the amount of bacteria according location under analysis

\begin{tabular}{|c|c|c|c|c|}
\hline & Place of harvesting & & & \\
\hline Variable & $\begin{array}{l}\text { Tap-dental office } \\
\text { Average } \pm S D \text { (median) }\end{array}$ & $\begin{array}{l}\text { Tank of the unit } \\
\text { Average } \pm S D \text { (median) }\end{array}$ & $\begin{array}{l}\text { Syringe Tryplice } \\
\text { Average } \pm \mathrm{SD} \text { (median) }\end{array}$ & $\mathrm{p}$ value \\
\hline Colony ${ }^{\circ}$ Amount & $\begin{array}{l}911,00 \pm 3.081,28 \\
(27,50)\end{array}$ & $\begin{array}{l}|3939,2| \pm \mid 0947,28 \\
(|27| 0,00)\end{array}$ & $\begin{array}{l}23256,93 \pm 28528,50 \\
(I 80 I 5,00)\end{array}$ & \\
\hline Number Logarithm (Bacteria + I) & $\begin{array}{l}I, 33 \pm 1,25^{(\mathrm{A})} \\
(I 80 I 5,00)\end{array}$ & $\begin{array}{l}3,49 \pm 1,54^{(\mathrm{B})} \\
(18015,00)\end{array}$ & $\begin{array}{l}3,78 \pm 1,26^{(B)} \\
(180 I 5,00)\end{array}$ & $P(I)=I, 000$ \\
\hline
\end{tabular}

(*): Significant difference at $5.0 \%$ level.

(I): Using F Test (ANOVA) with repeated measurement in comparison to the Bonferroni Method. Obs. If the letters in parenthesis are distinctive and prove a significant difference between the corresponding locations.

Table 3 Mean, standard deviation and median of the content of chlorine and the turbidity (water characteristics) according to the harvesting location

\begin{tabular}{|c|c|c|c|c|}
\hline \multirow[b]{2}{*}{ Variable } & \multicolumn{4}{|l|}{ Place of Harvesting } \\
\hline & $\begin{array}{l}\text { Cistern } \\
\text { Average } \pm \text { SD (Median) }\end{array}$ & $\begin{array}{l}\text { Dental office tap } \\
\text { Average } \pm \text { SD (Median) }\end{array}$ & $\begin{array}{l}\text { dental unit tank } \\
\text { Average } \pm S D \text { (Median) }\end{array}$ & $p$ value \\
\hline & & & & $\mathrm{p}^{(1)}=0,648$ \\
\hline \multirow[t]{3}{*}{ Chlorine } & $I, 2 I \pm I, 02(I, I 7)$ & $1,22 \pm 1,02(1,30)$ & $0,21 \pm 0,46(0,02)$ & $\mathrm{P}^{(2)}=0,043^{*}$ \\
\hline & & & & $\mathrm{P}^{(3)}=0,005^{*}$ \\
\hline & & & & $\mathrm{P}^{(1)}=0,600$ \\
\hline \multirow[t]{2}{*}{ Turbidity } & $2,16 \pm 1,13(2,03)$ & I,7I士I,68 (I,3I) & $\mathrm{I}, 48 \pm 2,69(0,67)$ & $\mathrm{P}^{(2)}=0,345$ \\
\hline & & & & $\mathrm{P}^{(3)}=0,090$ \\
\hline
\end{tabular}

(*): Significant difference at $5.0 \%$ level.

(I): Using the Wilcoxon test between cistern and the office's tap; (2): Using the Wilcoxon test between the cistern and the dental unit tank; (3): Using the Wilcoxon test between the dental office tap and dental unit tank.

Citation: Fernandes MCR, Lima PB, Calazans MT, et al. The quality of water in dental offices from the public healthcare system of a Brazilian town: a study of the microbial, physical and chemical parameters.J Dent Health Oral Disord Ther. 2018;9(5):393-397. DOI: I0.15406/jdhodt.2018.09.004I5 


\section{Discussion}

Determining the quality of the water used in dentistry procedures means to analyse considering microbial (coliforms, heterotrophic bacteria), chemical (chlorine content) and physical (turbidity) parameters. For such, it was used as a standard the Ordinance 2.914/11 from the Brazilian Government Ministry of Health, which has got the National Surveillance Program of the Quality of Water to Human Consumption (Vigiágua), based on the principles of the National Health System (SUS), which plays a important role guaranteeing the quality and safety of water to human consumption in Brazil. In this regard, in theory, the water supplied through the supply network is considered potable, and therefore liable to be used by dental equipment. Thereby, at a healthcare facility, the water runs a course until reaching the oral cavity of a dental patient: water reservoir - tap - dental unit tank - three-way syringe. During this procedure, many factors can determine a quality control failure, justifying the research at issue, of which the sites studies of the cited harvesting and found to be congruent with several studies present in scientific literature. ${ }^{4,6-9}$

In this research, the results showed the water supplied by the supply network complies with the standards of drinkability on the coliforms content, once this type of microorganisms was not detected in the tanks (water reservoirs) at the healthcare facilities. This way, it would be expected that none of the existing tap inside the offices to present coliforms. However, this premises was not diagnosed to one facility, once it was found presence of total coliforms, as well values higher than $500 \mathrm{UFC} / \mathrm{ml}$ of heterotrophic bacteria, in one tap from one of the health facilities located in the town. The thermotolerant coliform, however, was not identified at none of the samples under study. So, it was observed a divergence regarding the results obtained by Xavier et al. ${ }^{7}$ which, in similar research, did not identified coliforms in the water harvested from the taps. The reason for this finding can be justified due to the possibility of contamination in the hydraulic installations of the facilities, ${ }^{10,11}$ may contain imperfections, leakages or other evidences capable of compromising the quality of water.

Regarding the chlorine content (minimum of $0.2 \mathrm{mg} / \mathrm{l}$ ) and turbidity (up to $5 \mathrm{uT}$ ), the global analysis of the town, the water supplied by the supply network can be considered within the standard established by the Ordinance (Table 3). The analysis of those parameters are fundamental, the colouration level grants a potential of disinfection, which can be justified by the low levels of infections by coliforms (total and thermotolerants) and the heterotrophic bacteria found at the facilities under study. According to Brito, Amorim and Leite, ${ }^{12}$ a concentration of $0.5 \mathrm{mg} / 1$ of free residual chlorine in the water is capable of an harmless satisfactory disinfection. In addition, the turbidity criteria ${ }^{13}$ indicates the presence of mineral particles or organic material in the water, capable of committing the quality of water. Even those being parameters essential to the standard established of the quality of water, them being very few that comes to a conclusion criteria of evaluation. ${ }^{14}$ When taking into consideration the dental unit tank, and generalising the healthcare facilities, the statistical analysis indicated that, regarding the coliforms (total and thermotolerants), the water from the harvesting sites were inside the standards, coliforms only found in two samples, likewise Araújo, Lopes and Silva. ${ }^{15}$ However, the analyse of the heterotrophic bacteria, on the other hand, showed that all the samples of water found in unfit to human consumption, demonstrating average values superior to $13,000 \mathrm{UFC} /$ $\mathrm{ml}$ (Table 2). Levels of similar contamination were observed in many scientifical findings. ${ }^{4,9,16}$ Brazilian legislation establishes 500UFC/ $\mathrm{ml}$ as the maximum limit in order to classify the water as adequate, as to American Dental Association, this values should not exceed 200UFC/ml. Paixão ${ }^{17}$ reported that, findings such as this, could result in unfitted conditions of the use of the tanks. In the present study, the professionals relate that, at the end of the day, the liquid content would be kept in the tanks without any cleaning routine. In addition, the average of chlorine content at the tanks where below the lowest limit proposed by Brazilian Legislation (Table 3).

When the dental staff from the healthcare facilities under study were questioned about the source of the water in the tanks, it was determined that most of them were not supplied by the public system. Instead, the tanks were filled with mineral water. This type water did not show the free chlorine ions, ${ }^{18}$ being inefficient in the prevention of the contamination and development of biofilms in the interior of the tank. Reassuring the reports from Williams, Johnston \& Johnson, ${ }^{16}$ which observed the usage of distilled water or even sterilised (chlorine free) at the tanks is incapable to prevent the microbial growth. Paixão (2006) studies demonstrated that a intermittent colouring in concentrations between 0.5 and $1 \mathrm{ppm}$, every ten minutes, can reduce the amount of bacteria from 100,000UFC to around 100UFC/ml. ${ }^{17}$ Thereby, the Brazilian Health Surveillance Agency - responsible for the regulations of products and services regarding the health of the population - recommends and additional supplement of chlorine to the water used in the tank, in the portion of $500 \mathrm{ml}$ of water to $0.3 \mathrm{ml}$ of sodium hypochlorite $1 \% .{ }^{19}$ In dental offices, the water reaches the patients mouth through the actuation of the three-way syringe. For this purpose, the liquid runs the lines of the equipment until the end of the system. The present work observed a tendency of growth in the heterotrophic bacteria quantitative in comparison to the samples in the tanks $(13,939.21 \mathrm{UFC} / \mathrm{ml})$ and the three-way syringe $(23,256.93 \mathrm{UFC} /$ $\mathrm{ml}$ )-Table 2. According to Ferreira ${ }^{20}$ there is a possibility of formation of the biofilms at the surfaces where the water flows in the dental equipment, resulting as well in high bacterial levels in suspended matter in the water that runs the pipes. Mostly, the harvested organisms from the system are water bacteria Gram-negative noncoliforms. Nonetheless, according to the author, a greatest part of the species found had a capacity to be pathogenic above all in immunocompromised individuals. In addition, the water from the cooling for the rotary equipment, used in the turbines and micro motors, are subject to the contamination due to the reflux of organic material to the interior of this pieces. ${ }^{19}$ Thus, these equipment can be declared a source of a crossed infection due to the difficult effective and correct sterilisation the internal lines, as the bearing inside the turbine, existing then the possibility of reflux in the water system due to the pneumatic system..$^{21}$ The findings of this search in the Brazilian town described and alarming situation and demonstrated amongst the problems found, it highlights the using of a inadequate source of water, as the permanency of water in the interior of the tabulations, allowing a humid environment and favourable to the maintenance and the microbial growth. Accordingly, there is a necessity to adequate the services to promote population health. So, strategies to assure the quality to the water of the dental equipment becomes urgent, as such: daily drainage of the water lines and dry maintenance during the evening and at weekends; use of sterilised hands parts with anti-reflux valves and use sterile water with addition of chlorine in the tanks. 


\section{Conclusion}

The results obtained showed the water used in the dental equipment in the public system of Cabo de Santo Agostinho are not in accordance with the microbiological standards and chemical established by the Ministry of Health of the Brazilian Government. Only in the turbidity requirement has the water been considered satisfactory. The results demonstrate the necessity of an effective periodic control of the microbiological and chemical quality of the water, as the acting on the protocols of biosafety regarding the handling of the water in dental Offices.

\section{Acknowledgements}

None.

\section{Conflict of interest}

The author declares no conflict of interest.

\section{References}

1. Brazil: Ministério da Saúde. Portaria nº 2.914. 2011.

2. Navia SÁ, Torres SME, Torres DME. Calidad del agua de unidades odontológicas. Rev Publicación Científica en Ciencias Biomédicas. 2012;10:101-110.

3. Dental unit waterlines: approaching the year 2000. ADA Council on Scientific Affairs. J Am Dent Assoc. 1999;130:1653-1664.

4. Souza-Gugelmi MCM, Lima CDT, Lima SNM, et al. Microbial contamination in dental unit waterlines. Braz Dent J. 2003;14:53-57.

5. Galvão CF, Motta GF, Alvarez-Leite ME. Analise quantitativa da contaminação da água das tubulações e equipamentos odontológicos. Arquivo Brasileiro de Odontologia. 2006:3-9.

6. Chibebe PCA, Ueno M, Pallos D. Biossegurança: avaliação da contaminação da água de equipamentos odontológicos. Rev Biociênc. 2002;8:53-59.

7. Xavier HVM, Bulla JR, Luiza LM, et al. Análise bacteriológica da água de equipos odontológicos. Acta sci. 2000;22(2):631-636.

8. Watanabe E. Avaliação do nível de contaminação microbiana da água de equipo odontológico pelo método PetrifilmTM AC. Rev Biociên. 2006;12:68-75.
9. Szymanska J, Sitkowska J. Opportunistic bacteria in dental unit waterlines: assessment and characteristics. Future Microbiol. 2013;8(5):681-689.

10. Pankhurst CL, Johnson NW. Microbial contamination of dental unit waterlines: the scientific argument. International Dental Journal. 1998;48:359-368.

11. Díaz CG. La evaluación de la calidad microbiológica del agua em unidades dentales. Rev Cubana de Higiene y Epidemiologia. 2009;47(3):1-10.

12. Brito LTL, Amorim MCC, Leite WM. Qualidade da água para consumo humano. Embrapa. 2007:1-16.

13. Correia A, Barros E, Silva J, et al. Análise da turbidez da água em diferentes estados de tratamento. VIII ERMAC. 2008;8:1-5.

14. Resende LCC, Santiago FS. Avaliação do grau de potabilidade da água usada para procedimentos odontológicos do serviço público do município de Ipatinga MG. Ver CROMG. 2013;14(1):13-18.

15. Araújo CM, Lopes-Silva MAS. Análise da qualidade da água de reservatórios de equipamentos odontológicos. Rev Biociênc. 2002;8(1):29-36.

16. Willians JF, Johnston MA, Johnson B. Microbial contamination of dental unit waterlines: prevalence, intensity and microbiological characteristics. J Am Dent Assoc. 1993;124:59-66.

17. Paixão MS. Análise bacteriológica da água utilizada nos equipos odontológicos do serviço público de aracaju/se. Ficha Catalográfica Elaborada Pela Biblioteca da Saúde/ufs. 2006:1-50.

18. Rebelo MAP, Araujo NC. Águas minerais de algumas fontes naturais brasileiras. Rev Ass Med Brazil. 1999;45(3):255-260.

19. Brazil. Serviços Odontológicos: Prevenção e Controle de Riscos/ Ministério da Saúde, Agência Nacional de Vigilância Sanitária - Brasília. 2006. $156 \mathrm{p}$.

20. Ferreira MRR. Análise microbiológica do biofilme nas linhas de água de equipamentos de medicina dentária. Monografia (Especialização): Curso de Medicina Dentária, Universidade Fernando Pessoa; 2009. 79 p.

21. Barreto ACB, et al. Contaminação do ambiente odontológico por aerossóis durante atendimento clínico com uso de ultrassom. Braz J Periodontol. 2011;21(2):79-84. 